DOI 10.4467/25439561KSR.18.007.9365

ALEKSY KUCY (D) https://orcid.org/0000-0001-6655-6886

Uniwersytet Marii Curie-Skłodowskiej

Lublin

\title{
NIEWYKONALNA MISJA: \\ METROPOLITA ANTONI BLOOM NA TLE ROSYJSKIEJ EMIGRACJI RELIGIJNEJ XX WIEKU
}

\author{
IMPOSSIBLE MISSION: \\ METROPOLITAN ANTONI BLOOM AGAINST THE BACKGROUND \\ OF THE RUSSIAN RELIGIOUS EMIGRATION OF THE 20TH CENTURY
}

\section{Streszczenie}

Oddany życiu liturgicznemu Kościoła, posiadający wewnętrzną skłonność do refleksji duchowej i kontemplacji, metropolita Antoni swoją gorliwą modlitwą i płomiennym słowem zapalił w niezliczonych ludzkich sercach - nie tylko adeptów prawosławia, ale też innych wyznań - wiarę w Boga i miłość do Niego. Swoją osobistą drogę do Boga rozpoczął w wieku 14 lat, kiedy w trakcie pierwszego w swoim życiu, przemyślanego i wnikliwego czytania Ewangelii, przeżył osobiste mistyczne spotkanie z Chrystusem. Towarzysząca temu wydarzeniu przemiana świadomości hierarchy polegała na postrzeganiu świata i ludzi przez pryzmat Bożej miłości, definitywnie wyznaczyła ona dalszą, jakże niezwykłą drogę życiową przyszłego zwierzchnika Kościoła prawosławnego w Anglii.

Abstract

Dedicated to the liturgical life of the Church, endowed with the genuine inclination to spiritual reflection and contemplation, with his fervent prayer and encouraging word, Metropolitan Anthony lit faith and the love of God in countless human hearts, and not just those of the students of Orthodoxy but of other religions, too. He embarked upon his personal journey to God at the age of 14 when he experienced a personal mystical encounter with Christ during 
his first thoughtful and in-depth reading of the Gospel. The accompanying transformation of consciousness consisted in a new perception of the world and people through the lens of God's love and determined the extraordinary way of life of the future superior of the Orthodox Church in England.

Słowa kluczowe: emigracja rosyjska, Kościół prawosławny, metropolita Antoni Bloom Keywords: Russian emigration, the Orthodox Church, metropolitan Antoni Bloom

Kiedy 6 czerwca 1914 roku w Lozannie urodził się Andrzej, syn Kseni i Borysa Bloomów, nikt z jego bliskich nie mógł przypuścić, że będzie on jednym z najwybitniejszych prawosławnych hierarchów XX wieku. Nikt nie spodziewał się też tego, że w wyniku pierwszej wojny światowej, mającej wybuchnąć miesiąc po urodzeniu się najmłodszego Blooma, dojdzie do zmian geopolitycznych, które bezpośrednio odbiją się na losach tej rodziny oraz wszystkich Rosjan.

Popularność Antoniego Blooma - kiedyś i obecnie - zawsze wiązała się nie tyle z jego darem krasomówstwa i sposobem prezentacji poglądów, co z wewnętrzną głębią poruszanych zagadnień. Zdaniem ihumena Piotra (Mereszcinowa) ${ }^{1}$, na tle prawosławnych teologów XX wieku postać metropolity Antoniego wyróżnia się pięcioma głównymi cechami: stylem pasterskim, ewangelizmem, eklezjologia, wyjątkowym brakiem aberracji duchowej właściwym dobie współczesnej oraz związanym z tym zjawiskiem swoistym „outsiderstwem” na tle panujących tendencji we współczesnym życiu Kościoła prawosławnego ${ }^{2}$. Powyższe kryteria można uzupełnić o kolejne, decydujące o dodatkowym ciężarze gatunkowym myśli teologicznej metropolity, do których zaliczyć należy wewnętrzny psychologizm, antropocentryzm i chrystocentryzm. Owszem, miarą nauczania teologicznego i działalności pasterskiej nie jest myśl sama w sobie, lecz efekty misji ewangelizacyjnej, która w przypadku Antoniego Surożskiego była bardzo pokaźna. W Wielkiej Brytanii, gdzie działał hierarcha, od początku lat pięćdziesiątych XX stulecia do początku XXI wieku z kilkuosobowej wspólnoty prawosławnej rozwinęła się potężna diecezja surożska licząca kilkadziesiąt parafii ${ }^{3}$.

${ }^{1}$ Ihumen Piotr, świec. Walenty Mereszcinow - współczesny rosyjski duchowny prawosławny, ihumen, katecheta, misjonarz, publicysta.

${ }^{2}$ Zob. Петр (Мерещинов) игумен, Жизнь православного христианина в современном мире (на примере митрополита Антония), [w:] Духовное наследие митрополита Антония Сурожского. Материаль Первой международной конференции 28-30 сентября 2007 г. Москва, red. Е. Майданович, Е. Садовникова, М. Уманцева, Москва 2008, ss. 16-25.

${ }^{3}$ Zob. szczegółowe informacje o historii i stanie diecezji surożskiej na oficjalnym portalu diecezji: http://www.sourozh.org [dostęp: 27.08.2018]. 
Dla nikogo dziś nie jest tajemnicą, że rosyjscy emigranci podejmowali liczne próby duchowej interpretacji wydarzeń rewolucyjnych, swojego wygnania oraz uzmysłowienia sobie znaczenia roli, jaką mieli odegrać - każdy z osobna i wszyscy razem - w tym procesie. Słuszna wydaje się teza, że tematem wiodącym tych przemyśleń była „misyjność” mająca bezpośredni związek z Opatrznością a zakładająca realizację przez rosyjskich wygnańców określonych zadań historyczno-religijnych, nie tylko w Europie Zachodniej, ale i w samej Rosji. Swoją działalnością twórczą emigracja uzmysłowiła światu tragiczność rewolucji, pokazała do czego człowiek jest zdolny w różnych systemach społecznych, prezentując Zachodowi „rosyjską ideę" jako syntezę doświadczenia ogólnoludzkiego, korzystnego dla zamieszkujących go narodów ${ }^{4}$.

Powyższe dominanty generowały również linię myślenia społeczno-politycznego, gdzie nadrzędną ideą stawała się „,Wolna Rosja”, wolna nie tylko od komunizmu, ale i od wszystkich wrogich rosyjskiej mentalności ideologii. Dlatego też emigracja stanowiła jednocześnie tragedię i szansę na zachowanie rosyjskiej kultury, zaś liczba wybitnych naukowców, literatów, filozofów i działaczy religijnych stanowiła gwarancję sukcesu tej misji. Emigracyjny wymiar cerkiewny, zagadnienia wiary i religii Rosjan na wygnaniu są obecnie szeroko badane przez reprezentantów polskiej i zagranicznej nauki. Jednym z czynników emigracji religijnej, podkreślanym przez badaczy, a wpływających na decyzję opuszczenia kraju było prześladowanie Rosyjskiego Kościoła Prawosławnego, którego skala po wydarzeniach 1917 roku z roku na rok się powiększała. Powszechny Rosyjski Sobór Cerkiewny zdążył co prawda wprowadzić kardynalne zmiany w zarządzaniu i organizacji życia cerkiewnego Rosji, jak chociażby przywrócenie urzędu Patriarchy Moskiewskiego, ale rewolucja i wojna domowa wyrządziły Kościołowi niebywałą krzywdę. Walka bolszewików z religią i duchowieństwem skutkowała setkami tysięcy ofiar w osobach wierzących, ale przede wszystkim w księżach i ich rodzinach. Obiektywna ocena tych wydarzeń w Rosji mogła nastąić jedynie po upadku Związku Radzieckiego, jednakże już kilkadziesiąt lat wcześniej dzięki emigracji rosyjskiej postawiono odpowiednie akcenty moralne i wydano werdykt intelektualny w stosunku do ideologii komunistycznej. Iwan Iljin w swoim czasie tak odnosił się do powyższego zagadnienia:

„Chrześcijaństwo uczy ludzi cierpliwości. Chrześcijanin powierza siebie woli Bożej, co też obejmuje jego życie ziemskie. Powinien on $w$ duchu pokonywać cierpienia, choroby, nędzę. Bolszewik z kolei propaguje niecierpliwość, sprzeciw, protest. On żąda, grozi, skłóca i wywraca. Dąży on do odebrania innym siłą tego, czego mu właśnie brakuje"s.

\footnotetext{
${ }^{4}$ О. Гончаренко, Миссия русской эмиграции в XX веке, [w:] http://mir-politika.ru/3521-missiya-russkoy-emigracii-v-hh-veke.html [dostęp: 20.06.2018].

${ }^{5}$ И. Ильин, Кризис Безбожия, Москва 2005, s. 340.
} 
Jednakże błędne byłoby nadawanie emigracji uniwersalnego znaczenia $\mathrm{w}$ rozwoju duchowości rosyjskiej, jak to często jest czynione przez współczesnych badaczy powyższego zagadnienia. Owszem, można mówić o „masowym” nawróceniu się i powrocie rosyjskiej inteligencji emigracyjnej do prawosławia, życia sakralnego, wiary, duchowej wizji procesów historycznych, co można prześledzić na podstawie metamorfoz charakteryzujących wielu emigrantów rosyjskich. Niemniej jednak, gdy weźmie się pod uwagę przedrewolucyjny poziom rozwoju życia monastycznego, rosyjskiej szkoły teologicznej i filozofii religijnej, to okres emigracyjny można określić nie inaczej jak następstwo tej twórczości, kontynuację tradycji teologii rosyjskiej, której początki sięgają XIX wieku. Z drugiej strony, emigracja pozwoliła na to, aby, według słów ks. Aleksandra Schmemanna, „reszta się ocaliła”. I nie tylko się ocaliła, lecz dała nowy początek rosyjskiej twórczości religijnej ${ }^{6}$. Emigracja stała się najlepszą okazją do właściwego odrodzenia wiary, pozbawionego tak wyraźnego obskurantyzmu, jaki towarzyszył w XIX wieku tak zwanemu narodnictwu. Powrót do prawosławia, twierdził Mikołaj Zernow, stanowił „koniec błąkania się w poszukiwaniu prawdy"'. Mimo trudności społeczno-politycznych życie kulturalne emigrantów rosyjskich zaczęło nabierać wyraźnych kształtów dzięki wewnętrznej sile duchowej, która rzecz jasna płynęła z religii ${ }^{8}$.

Przeżycie utraty własnej państwowości stało się możliwe dzięki sferze duchowej. Prawosławie sprawiło, że Rosjanie, którzy pozostali w Rosji radzieckiej i Rosjanie na wygnaniu nadal byli ,jednym ciałem”. Powrót do narodowej wiary stanowił dla nich ukojenie i wewnętrzne wsparcie w walce $\mathrm{z}$ udrękami i trudnościami życia na emigracji. Kościół prawosławny odegrał kluczową rolę w życiu społeczno-kulturalnym i duchowym. Wielu emigrantów powróciło do wiary, ponieważ uświadomili sobie współudział w tragedii narodowej. Prawosławne cerkwie dostarczały sił, były „głównymi bastionami emigracji w walce o przetrwanie"

Mówiąc o roli Kościoła prawosławnego w życiu rosyjskiej diaspory XX wieku, nie sposób pominąć negatywów, które cechowały rosyjskie życie cerkiewne w tym okresie. Najważniejszym z nich było oddzielenie się od Rosyjskiego Kościoła Prawosławnego tak zwanego Rosyjskiego Kościoła Prawosławnego poza granicami Rosji. Nie wnikając w szczegóły losów historycznych siostrzanych jurysdykcji prawosławnych, w odróżnieniu od Patriarchatu Moskiewskiego zmuszonego do funkcjonowania $\mathrm{w}$ antyreligijnym systemie radzieckim, duchowieństwo prawosławne

${ }^{6}$ Прот. А. Шмеман, Конец и начало, [w:] idem, Собрание статей 1947-1983, Москва 2009, s. 650 .

${ }^{7}$ Н. Зернов, Русское религиозное возрождение ХХ века, Paris 1991, s. 225.

${ }^{8}$ М. Назаров, Миссия русской эмиграции, Москва 1994, t. 1, s. 30.

${ }^{9}$ Ibidem, s. 37. 
zagranicą działało w warunkach wolności wyznaniowej i politycznej. Było to niewątpliwie dodatkową przyczyną uwydatnienia się szczególnej religijności właśnie wśród emigrantów, nie tylko w wymiarze sakralnym, ale też i społecznym, czego dowodem były współczucie i ofiarność w pomocy rodakom znajdującym się w ciężkich warunkach bytowych. Nikita Struwe zwraca uwagę, że owa wolność nie polegała wyłącznie na braku prześladowań, jak to miało miejsce w Rosji, lecz na pełnej samodzielności i braku „opieki” ze strony państwa.

„Emigracja znalazła się na wolności, była wolna nie tylko od prześladowań, ale i państwowego wsparcia. [...] Na emigracji pytanie o relacje pomiędzy państwem a Kościołem w ogóle nie padło. Kościół był wolny od opieki państwa, od ucisku państwa, od wymagań państwa, $w$ dodatku był on porozrzucany pomiędzy różnymi bytami państwowymi” ${ }^{\prime 10}$ - konstatuje badacz.

Rozpatrując wewnętrzny stosunek emigrantów do wygnania i ich ocenę tego zjawiska, nie można nie wspomnieć o licznej grupie osób reprezentujących zupełnie inny tok myślenia, a którą można nazwać pokoleniem „wstecznego myślenia”. Grupa ta była mentalnie i duchowo przywiązana do poprzedniego systemu politycznego, zaś jego upadek był odbierany w kategoriach eschatologicznych jako koniec historii, właściwie koniec też własnego życia. Na poziomie religijnym stosunek ten odzwierciedlił się w zawężeniu prawosławia do Rosji - tej, która istniała przed rewolucją 1917 roku. Dlatego też Kościół prawosławny odbierany był przez tę grupę nie jako dobra nowina o zbawieniu, lecz jako „ostatnia wysepka ojczyzny”.

Dla nas interesujące są przemyślenia metropolity Antoniego Blooma, który w zjawisku emigracji rosyjskiej XX wieku, podobnie do większości sobie współczesnych, upatrywał krzyż narodu rosyjskiego powołanego do spełniania podstawowej misji niesienia światła prawosławia Europie Zachodniej. Mówił:

„Opuściliśmy Rosję mimo swej woli, zostaliśmy zmuszeni do opuszczenia swej ojczyzny, dlatego unieśliśmy ją ze sobą w sercu. Pozostawaliśmy Rosjanami do najgłębszego zakątka duszy. Rosja była dla nas wszystkim. Pamiętam, że w wieku 14 lat przyszło mi jechać z jedną osobą w pociagu do szkoły. Ona mnie wtedy zapytała:

- Dlaczego nie nabywasz francuskiego obywatelstwa?

Odpowiedziałem wtedy:

- Wolę umrzeć jako Rosjanin, niż żyć jako cudzoziemiec"11.

${ }^{10}$ Н. Струве, Духовный опыт русской эмиграции, [w:] idem, Православие и Культура, Москва 2000, s. 298.

${ }^{11}$ Апостол любви: выбор пути, reż. В. Матвеева, Санкт-Петербург 2005, min. 00:28:4800:30:20. 
Jednak metropolita Antoni nie tylko nie popadał w rozpacz z powodu wygnania rosyjskiej emigracji, ale i dostrzegał w niej szansę i możliwość odrodzenia życia duchowego poprzez odkrycie utraconej w Imperium Rosyjskim eksterytorialności prawosławnej wspólnoty chrześcijańskiej. Myśl ta jest zgodna z odczuciami wszystkich emigrantów, którzy winili za rewolucję inteligencję rosyjską, mianowicie jej odejście od rosyjskiej tradycji i kultury, gdzie wymiar sakralny, religijno-cerkiewny odgrywał bodajże najważniejszą rolę. Hierarcha opisywał to w taki sposób:

„Tu na emigracji mieliśmy jedną olbrzymią przewagę: zostaliśmy wyrzuceni na zewnątrz, byliśmy samotni, obcy dla wszystkich, ale w efekcie poznaliśmy jedną prawdę, że każdy prawosławny jest dla mnie bliską osoba, bliską jak ojciec, brat, matka, siostra. Prawosławny to swój. Pamiętam, jeszcze jako chłopak szedłem ulicą lub jechałem metrem, to kiedy słyszałem język rosyjski, wtedy moja dusza triumfowała. Dorośli traktowali wówczas obce dzieci jako swoje, a dzieci - dorosłych jako swoich rodziców. To jest jedna strona. Ostatecznie, kiedy zaczęliśmy coś tworzyć, to czyniliśmy to według zasady, że jesteśmy obcymi w obcym świecie i swoimi wśród swoich. Druga to ta, która jest bardzo ważna, a którą sobie uzmysłowiłem już kiedy dojrzałem, mianowicie że Bóg, który przed rewolucją był „Szlachcicem” mieszkającym w ogromnych świątyniach, w rzeczywistości takim nie był, bowiem był jednym z nas. On był takim samym uchodźca, jakim my byliśmy, nie miał gdzie schylić głowy. Byliśmy bardzo biedni i tworzyliśmy bardzo ubogie świątynie, dosłownie w wymiarze tego pokoju [metropolita głową pokazuje na pokój, w którym odbywa się wywiad - autor], i że ta świątynia była dla Niego schroniskiem. On był obcy dla świata, został z niego wygnany. Lecz jacyś ludzie, dziesięcioro bądź niekiedy pięcioro, tworzyli takie miejsce, dokąd On mógł przyjść i powiedzieć - ,jestem u siebie”. Ci ludzie mnie kochaja, dadzą mi schronienie, dach nad głowa, są oni ubodzy jak ja. Lecz byliśmy świadomi, że niezależnie od głębi naszego ubóstwa: fizycznego, duchowego, zawsze będzie ono przewyższone przez ubóstwo otwartych ramion Chrystusa" 12 .

Ten szczególny akcent na ponownym odkryciu przez Rosjan-emigrantów prawd swojej wiary oraz jej praktycznego życiowego przełożenia, nowej rzeczywistości egzystencjalnej zawartej w nauce Chrystusa i w Nim samym, jest znamienny w badaniu duchowości emigracji rosyjskiej XX wieku. Powyższe podejście towarzyszyło wielu rosyjskim duchownym funkcjonującym poza swoim krajem, było ono zarówno przyczyną ich duchowych wzniesień, jak i jego skutkiem. Przykład metropolity Antoniego Blooma pokazuje słuszność interpretacyjną takiego podejścia i jeszcze raz potwierdza wnioski zawarte w większości prac badawczych na temat analizowanego zjawiska.

${ }^{12}$ Апостол любви: Сеятель, reż. В. Матвеева, Санкт-Петербург 2008, min. 00:39:55-00:43:22. 
Przyszły hierarcha urodził się w słynnym szwajcarskim mieście, gdzie rezydencję dyplomatyczną miał jego dziadek, pierwszy konsul Rosji w Lozannie - Mikołaj Skriabin $^{13}$. Ojciec metropolity - radca dworu, Borys Bloom (1884-1937), był na służbie w kilku miastach południowoazjatyckich. Pochodził ze skandynawskiego rodu Bloomów, którzy wraz z Holendrami, Duńczykami i innymi reprezentantami cywilizacji zachodniej byli zachęcani do zamieszkania w Rosji w czasach panowania Piotra Wielkiego. Na początku XX wieku rodzina lekarza Edwarda Blooma była już głęboko zakorzeniona w rosyjskiej kulturze i od kilku pokoleń wyznawała prawosławie $^{14}$. Matka metropolity, Ksenia, ukończyła słynny Instytut Smolny w Petersburgu. Była energiczną i wszechstronnie utalentowaną osobą, która władała kilkoma językami europejskimi ${ }^{15}$.

Po upadku Rządu Tymczasowego dyplomata Borys Bloom został bez pracy, a jego rodzina musiała znaleźć sobie nowe miejsce zamieszkania. Po długiej tułaczce ostatecznie znalazła się w 1923 roku we Francji. Szczególnie w pierwszym okresie swojego pobytu, rodzina Andrzeja, podobnie do wielu tysięcy Rosjan na uchodźstwie, ze względu na trudną sytuację materialną przeżyła dramat rozdzielenia. Ksenia Bloom wynajmowała w paryskim hotelu, gdzie pracowała, niewielki pokój. Nie wolno było jej jednak zapewnić tam noclegu swojemu dziecku, więc syn został oddany do szkoły-internatu na przedmieściach stolicy. Pani ze szlacheckiego domu pracowała jako sprzątaczka we francuskich domach, następnie jako recepcjonistka, a dopiero później jako pracownik biurowy ${ }^{16}$. Sam Andrzej oprócz rozterek z powodu mieszkania $\mathrm{z}$ dala od rodziców, do czego nie był przygotowany ani mentalnie, ani uczuciowo, przeżywał jeszcze jeden dramat. Związane to było ze szkolną przemoca, skutki której jeszcze długo odczuwał w życiu dorosłym. Doznania młodego emigranta sprawiły, że nie tylko nie wiódł „religijnego życia”, ale i stronił od Cerkwi. Jednak w życiu Andrzeja Blooma nastąpił zdecydowany przełom, który miał związek z jego aktywnością w Rosyjskim Chrześcijańskim Ruchu Studenckim w 1929 roku. W tym czasie na spotkanie z rosyjskimi dziećmi i innymi zainteresowanymi osobami został zaproszony ks. Sergiusz Bułgakow, ówczesny rektor Instytutu Teologicznego im. św. Sergiusza. Wychowawca grupy, zapraszając młodzież na rozmowę, uzyskał od większości odpowiedź odmowną, lecz Andrzeja udało mu się przekonać do pójścia na lekcję, jakkolwiek nie z powodów soteriologicznych. Ks. Sergiusz sprawił,

${ }^{13}$ Mikołaj Skriabin - rosyjski dyplomata, ojciec kompozytora Aleksandra Skriabina. Zob. И. Грезин, Николай Скрябин: первый российский консул в Лозанне, „Наша Газета”, [w:] http://www. nashagazeta.ch/news/12530 [dostęp: 21.06.2018].

${ }^{14}$ G. Crow, This Holy Man: Impressions of Metropolitan Anthony, New York 2006, s. 7.

${ }^{15}$ Антоний Митрополит Сурожский, Человек перед Богом, Москва 2000, s. 341.

${ }^{16}$ G. Crow, This Holy Man: Impressions of Metropolitan Anthony..., op.cit., ss. 23, 27. 
że młody Bloom sięgnął po Pismo Święte, by sprawdzić głoszoną w nim naukę. Podczas lektury Ewangelii według św. Marka szesnastoletni wówczas Andrzej doświadczył mistycznego spotkania z Chrystusem, które sprawiło, że od następnego dnia zaczął żyć inaczej niż dotychczas ${ }^{17}$.

Nie są znane szczegóły dotyczące świątyń prawosławnych, do których na początku swej drogi duchowej uczęszczał Andrzej Bloom. Najprawdopodobniej były to parafie $\mathrm{w}$ jakiś sposób związane z młodzieżowym ruchem emigracyjnym, do którego należał. Wiadomo natomiast, że w 1931 roku świadomie uczestniczył w życiu parafialnym jedynej w Paryżu świątyni należącej do Patriarchatu Moskiewskiego cerkwi pw. Trzech Świętych Hierarchów. Zatem w najważniejszym dla emigracji francuskiej konflikcie duchowym opowiedział się za Kościołem rosyjskim.

Można wyodrębnić dwa główne rodzaje przyczyn i motywacji, którymi kierował się Bloom w wyborze wspólnoty, w której chciał duchowo wzrastać. Do pierwszego z nich należą przesłanki natury, ujmijmy to konwencjonalnie, programowej. Bezsprzecznie związane one były z wychowaniem i umacniającym się światopoglądem narodowym, który młody mężczyzna ukształtował poprzez uczestnictwo w młodzieżowym ruchu emigracyjnym. Choć z racji swojego wieku Andrzej nie mógł należeć do Bractwa św. Focjusza, jego postawa względem wydarzeń w emigracyjnym życiu Kościoła była w wielu punktach zbieżna ze stanowiskiem jego członków. Metropolita wspominał:

„Pytają mnie, dlaczego należę do Kościoła moskiewskiego i dlaczego wybrałem go w 1931 roku, kiedy miałem 17 lat? Były dwie przyczyny. Po pierwsze, dlatego że zostałem nauczony, iż z Kościoła można odejść tylko wtedy, kiedy głosi on herezję. Kościół rosyjski nigdy nie głosił żadnej herezji. Po drugie, jest taka zasada, że kiedy wspólnota Kościoła, do której należysz, jest ciemiężona, kiedy znajduje się ona w stanie męczeństwa, kiedy jest prześladowana, to wtedy jest właśnie odpowiedni czas, kiedy należy ogłaszać swoją przynależność do niej. W tym czasie, jeśli jest taka możliwość, to należy być jej niezawisłym głosem, jeśli zaś nie ma ktoś głosu ze względu na wiek, okoliczności, to wtedy przynajmniej należy zachowywać wobec niej swoją wierność; zaś jeśli jest taka konieczność, to należy znosić wszelkie obelgi z jej powodu, aby chociażby w taki mały sposób uczestniczyć w jej zhańbieniu"18.

Tłumacząc swoją wierność Kościołowi matce, hierarcha uzasadniał postawę podobnych do niego emigrantów, którzy nie chcieli osąazać ani Kościoła rosyjskiego, ani tych hierarchów, na barkach których spoczywała odpowiedzialność za jego losy w bolszewickiej Rosji. Swoje własne doświadczenia życia na emigracji, nędzy

\footnotetext{
${ }^{17}$ Антоний Митрополит Сурожский, Человек перед Богом..., op.cit., ss. 362-363.

18 Апостол любви: встречи в России, reż. В. Матвеева, Санкт-Петербург 2007, min. 00:05:08:00-00:06:18.
} 
i wszelkich ograniczeń Antoni Bloom uznawał za nic, w stosunku do represji i innych okoliczności, w jakich znalazła się wspólnota Kościoła prawosławnego w ZSRR. $\mathrm{Z}$ tego względu uważał, że w żaden sposób nie można było osądzać metropolity Sergiusza (Stragorodskiego) za podejmowane w tamtych warunkach kroki.

„Nie osądzaliśmy go w tym sensie, że nie wiedzieliśmy czego on nie powinien był robić, a co powinien. Wiedzieliśmy jedynie, że gdy Kościół znajdował się pomiędzy młotem a kowadłem, kiedy cały ciężar spraw legł na jego barki, on nie przestraszył się i stał na swoim miejscu. Nie sądziliśmy o nim w świetle tych kompromisów, na które powiedzmy był zmuszony iść w owym czasie, sądziliśmy o nim w świetle innych wydarzeń. Napisał kilka akatystów, między innymi do św. Serafina z Sarowa i Przenajświętszej Bogurodzicy. Po tych faktach wyrabialiśmy o nim zdanie, bowiem te akatysty pisał on, kiedy przebywał w więzieniu. Widzieliśmy wtedy, że oto człowiek siedzi w więzieniu, a całą swą duszą przebywa w tajemnicy obcowania z Bogiem. Takiej osoby nikt nie powinien osądzać"19.

Jeśli osądzanie hierarchii rosyjskiej metropolita uważał za rzecz niedopuszczalną, to odejście ze struktur kanonicznych Kościoła prawosławnego w Rosji było dla niego równoznaczne ze zdradą. Jako Andrzej Bloom, a następnie kapłan i biskup zawsze postrzegał siebie jako nieodłączną część rosyjskiego narodu i rosyjskiego Kościoła. Za tę postawę niejednokrotnie musiał płacić swoim osobistym autorytetem w środowisku emigracyjnym.

Jako drugi rodzaj motywacji, bardziej istotny z mistycznego punktu widzenia, należy wymienić stosunek Andrzeja Blooma do swojego ojca duchowego, którego odnalazł po długich poszukiwaniach właśnie w świątyni moskiewskiej. Służyło to niejako potwierdzeniu słuszności dokonanego wyboru i stwarzało dobre rokowania na przyszłość duchową.

„Nikt nie może spotkać się z wiecznością, jeśli nie zobaczy w oczach lub na twarzy chociażby jednej osoby światła wiecznego życia"²0

- taki aksjomat z życia mistycznego metropolita Antoni często zwykł powtarzać w swoich rozważaniach teologicznych. Tego samego określenia użył w stosunku do swojego ojca duchowego - archimandryty Atanazego (Nieczajewa) ${ }^{21}$.

${ }^{19}$ Митрополит Сурожский Антоний, Беседы. Октябрь 1993. Почему я принадлежу к РПЦ, reż. В. Матвеева, Санкт-Петербург 2006, min. 00:03:30-00:04:25

${ }^{20}$ Апостол любви: выбор пути..., ор.cit., min. 00:01:37-00:01:47.

${ }^{21}$ Ksiądz archimandryta Atanazy, świec. Anatol Nieczajew - rosyjski duchowny, hieromnich. Zob. A. Нивьер, Православные свящзеннослужстели, богословы и церковные деятели русской эмиграиии в Западной и Центральной Европе 1920-1995. Биографический справочник, Москва 2007, s. 87. 
Ostatecznym efektem zmagań duchowych Andrzeja stało się pragnienie życia mniszego w w monasterze Wałaam. Na przeszkodzie temu znalazło się jednakże kilka czynników, jednym z nich był paszport nansenowski. Te i inne okoliczności życiowe uniemożliwiały mu szybką realizację religijnych pragnień. Szukający zbawienia młody rosyjski emigrant postanowił, że ukończy medycynę i jako lekarz będzie pomagał niezamożnym Rosjanom mieszkającym w różnych miejscach Francji. Planował przyjąć w ukryciu postrzyżyny mnisze (i kapłańskie) i w ten sposób spełnić się również jako charytatywny kapłan dla wybranej rosyjskiej społeczności emigracyjnej. Stało się to nie bez udziału Borysa Blooma, z którym Andrzej był w ciągłym kontakcie, mimo jego nieobecności w rodzinie. Ojciec dał mu taką radę:

„Pamiętam, że ojciec powiedział mi: co może być wspanialsze od życia wierzącego lekarza? Możesz wtopić w swoją działalność całą Ewangelię, cały twój szacunek do ludzi, całą cnotę, do której tylko jesteś zdolny, całą miłość, która z czasem może w tobie wzrosnąć, całą twoją wiarę nie tylko w Boga, ale i wiarę w człowieka"22.

Kierując się tą wskazówką, Andrzej Bloom postanowił studiować medycynę na Sorbonie. Podszedł do tego na tyle poważnie, że przed złożeniem dokumentów na Wydziale Medycznym skończył dwuletni kurs fizyki, chemii i biologii na Wydziale Nauk Przyrodniczych, przygotowujący go do właściwych studiów. W tym czasie jego szczególne zainteresowanie budziły nauki ścisłe, takie jak biologia i chemia. Podążając z kolei za radą Maurice Curie, bratanicy Pierre'a Curie, Andrzej zainteresował się też fizyka, uznając tę dyscyplinę za „niezwykle głęboką (...), pełną harmonii i piękna"23. Uroda stworzonego świata, jego budowa, nie tylko zachwycały Andrzeja, ale także formowały w jego świadomości jeszcze silniejszą więź z Twórcą tej rzeczywistości, stanowiąc niejako uzupełnienie religijnego światopoglądu - tzw. „świecką teologię".

Zdobyte kwalifikacje umożliwiły londyńskiemu hierarsze zbudowanie warsztatu badawczego niezbędnego do samodzielnego zgłębiania nauk teologicznych i mistyki chrześcijańskiej. W sposobach nauczania oraz traktowania zjawisk religijnych i duchowych zawsze można odnaleźć ślady profilu edukacyjnego. W centrum uwagi metropolity Antoniego zawsze znajduje się człowiek i jego wewnętrzy świat: biologiczny i duchowy. Odrębny wątek stanowi stricte pasterska działalność hierarchy, tutaj należy również zwrócić uwagę na fakt kilkuletniej praktyki lekarskiej, która poprzedzając posługę duszpasterską - wywarła na nią bezpośredni wpływ.

Hieromnich a następnie metropolita odnosił się do wszystkich podopiecznych jak lekarz. W odróżnieniu od niektórych duchownych traktował każdą osobę w sposób

\footnotetext{
${ }^{22}$ Апостол любви: выбор пути..., min. 00:05:33-00:06:03.

${ }^{23}$ Cyt. za: G. Crow, This Holy Man: Impressions of Metropolitan Anthony..., op.cit., s. 55.
} 
integralny, postrzegając człowieka w dwóch zasygnalizowanych wymiarach antropologicznych. Pomogły mu w tym bez wątpienia wykształcenie i praktyka lekarska, znajomość nie tylko ludzkiego ciała, ale i wiedza z zakresu psychologii i psychiatrii.

Interesującym faktem jest, że swoją postawę wobec śmierci hierarcha wypracował w okresie wojny, pracując jako chirurg wojskowy. Po ukończeniu studiów na uniwersytecie w 1939 roku Andrzej Bloom został powołany do wojska i przez pierwszy rok służył we francuskiej armii na południowym froncie jako chirurg polowy w randze kapitana. Było to możliwe nie tylko dzięki ukończonemu Uniwersytetowi Paryskiemu, ale i obywatelstwu francuskiemu, uzyskanemu w 1937 roku. Po kapitulacji Francji wrócił do Paryża i brał czynny udział we francuskim ruchu oporu, zaś po alianckiej operacji desantowej znowu wrócił do armii, biorąc udział w kampanii wojskowej. Czas drugiej wojny światowej stanowił bardzo ważny etap w rozwoju duchowym metropolity, który często narażając się na niebezpieczeństwo, ratował życie innych ludzi.

Wojenna służba lekarska była dla Andrzeja cennym, choć trudnym doświadczeniem. Ludzie ginęli nie tylko na polu bitwy, ale i w szpitalach polowych. Chirurg Bloom pozostawał w ciagłym kontakcie ze śmiercią, żegnając umierających żołnierzy i towarzysząc im w odejściu do świata niematerialnego. Dzięki tej szczególnej praktyce zyskał zdolność radzenia sobie z emocjami związanymi z przeżywaniem śmierci i odporność na stres. Głównym przymiotem nowej wizji, która odkrywała się przed nim w obliczu śmierci była cisza, którą odczuł po śmierci ojca, zaś nowy wymiar życia dawał się poznać wyłącznie jakimś nadprzyrodzonym zmysłem.

W 1943 roku archimandryta Atanazy przyjął od Blooma wieczyste śluby mnisze. Andrzej dostał nowe imię zakonne - Antoni.

Po zakończeniu II wojny światowej mnich Antoni kontynuował pracę lekarza w swoim gabinecie na rue-Saint-Louis-en-l'Île nr 10 w Paryżu, jednocześnie pracując jako nauczyciel w jedynym gimnazjum rosyjskim w stolicy Francji. Czasy wojny zmusiły go do podjęcia dodatkowej pracy i nauczania nawet tych przedmiotów, które nie były związane z jego wykształceniem i zawodem lekarza-chirurga, między innymi geografii, języka czy gimnastyki. Weronika Łosska, która była wówczas uczennicą tego gimnazjum, wspomina swojego nauczyciela jak osobę, która mimo znacznej różnicy wiekowej potrafiła znaleźć z wychowankami wspólny język i dać im cenne wskazówki niezbędne do prawidłowego rozwoju psychofizycznego. Przy okazji pracy w szkole Antoni zaczął organizować w swoim domu sesje biblijne, czyli adresowane do młodzieży spotkania poświęcone odrębnym zagadnieniom Pisma Świętego. Wrócił zatem do aktywności, która tak go pasjonowała w latach 30., a z której musiał zrezygnować na polecenie swojego ojca duchowego. Być może właśnie ten fakt sprawił, że znowu włączył się w działalność Rosyjskiego Chrześcijańskiego Ruchu Studenckiego. 
W tym czasie szczególnie blisko współpracował z rosyjskimi teologami, między innymi Włodzimierzem Łosskim, Mikołajem Zernowym czy Symeonem Frankiem. Prawdopodobnie jego udział w ruchu młodzieżowym zaowocował w 1947 roku wyjazdem grupy członków RCRS na konferencję teologiczną do Anglii, organizowaną cyklicznie od 1928 roku przez rosyjskich i anglikańskich teologów. Wtedy, pod koniec lat dwudziestych, podjęli oni decyzję powołania Bractwa Świętego Męczennika Albana i Świętego Sergiusza - organizacji działającej na Wyspach Brytyjskich na rzecz dialogu pomiędzy Kościołem prawosławnym a anglikańskim ${ }^{24}$. Podczas konferencji z wcześniej zadeklarowanego wystapienia musiał zrezygnować Włodzimierz Łosski, a zamiast niego głos zabrał mnich Antoni, który - choć nie był tak dobrze wykształconym i znanym teologiem jak Łosski - wywarł na słuchaczach imponujące wrażenie. Nie bez powodu opiekun duchowy sympozjum, ojciec Lew (Gillet) ${ }^{25}$, zasugerował Bloomowi rezygnację z medycyny na rzecz kapłaństwa w Anglii ${ }^{26}$. Sugestia francuskiego prawosławnego duchownego wsparła wcześniejszą propozycję święceń, którą mnich otrzymał ze strony urzędującego w Paryżu biskupa - Serafina (Łukjanowa) ${ }^{27}$, dlatego 33-letni Antoni zaczął poważnie myśleć o zmianie drogi życiowej.

Hieromnich Antoni Bloom przybył do Londynu 1 stycznia 1949 roku i miał tam pełnić posługę duszpasterza w Bractwie Świętych Albana i Sergiusza ${ }^{28}$. Przyjazd do stolicy Wielkiej Brytanii nowo wyświęconego kapłana-mnicha z Francji stanowił do pewnego stopnia sytuację kuriozalną. Wynikała ona głównie ze specyfiki środowiska, w którym powinien był budować życie religijne. Realia życia emigrantów rosyjskich na Wyspach Brytyjskich kardynalnie różniły się od tych, w których wychował się Andrzej Bloom. Tu wszystko było inaczej - pod względem społeczno-politycznym, materialnym oraz mentalnościowym. Anglia, w odróżnieniu od innych krajów

${ }^{24}$ Bractwo Świętego Albana i Świętego Sergiusza (ros. Содружество Святого Албания и Святого Сергия, ang. Fellowship of Saint Alban and Saint Sergius) powstało w 1928 roku jako odpowiedź na narastającą potrzebę dialogu pomiędzy wiernymi Kościoła prawosławnego a wyznawcami innych wyznań chrześcijańskich.

${ }^{25}$ Ksiądz archimandryta Lew, świec. Louis Gillett - francuski duchowny prawosławny Zachodnioeuropejskiego Egzarchatu Rosyjskiego Kościoła prawosławnego, pisarz religijny. Zob. Протоиерей Александ Мень, Библиологический Словарь, Москва 2002, t. 2, ss. 119-120.

${ }^{26}$ Zob. G. Crow, This Holy Man: Impressions of Metropolitan Anthony..., op.cit., ss. 86-87 i Антоний Митрополит Сурожский, Человек перед Богом..., op.cit., s. 377.

${ }^{27}$ Metropolita Serafin, świec. Aleksander Łukjanow - rosyjski hierarcha prawosławny. Święcenia biskupie przyjął w 1914 roku. Zob. Нивьер А., Православные священнослужители, богословы и церковные деятели русской эмиграџии в Западной и Центральной Европе 1920-1995: Биографический справочник..., ор.cit., s. 425.

${ }^{28}$ Митрополит Антоний Сурожский, Быть Русской Церковью богослужебно, богословски, эмоционально, „Церковный вестник” 2002, nr 23 (292), [w:] http://www.taday.ru/text/551475.html [dostęp: 27.06.2018]. 
Europy Zachodniej, nie była otwarta na przyjmowanie dużej liczby emigrantów rosyjskich po rewolucji 1917 roku, dlatego też dostanie się do tego kraju wymagało sporego wysiłku, który często kończył się niepowodzeniem. Prowadzono tu zupełnie inną politykę społeczną wobec uchodźców, zapewniając im odpowiednie do normalnego życia warunki materialne, co - jak pokazano wyżej - było ewenementem na tle powszechnie panującej biedy wśród Rosjan mieszkających we Francji. Hieromnich Antoni miał przed sobą nie lada wyzwanie - w nieznanych sobie dotąd realiach miał tworzyć wspólnotę religijną wyznającą rosyjskie prawosławie mówiącą w obcym języku, i dla ludzi, którzy byli dlań „,nowymi i często niepojętymi” ${ }^{29}$.

Politycznie było to także bardzo trudne zadanie, zwłaszcza wobec powszechnie panującego braku zaufania do Związku Radzieckiego i awersji do Patriarchy Moskiewskiego, który nolens volens znalazł się w orbicie wpływów bolszewickiego Kremla. Jak podaje Avril Pyman, stanowisko ojca Antoniego w ogóle nie było zrozumiałe dla Anglików. Duchowa córka hierarchy tłumaczy:

„Dawno w przypadku Anglii minęły te czasy, kiedy wierzono w boski wybór króla, dlatego monarchizm osoby, która jednocześnie utrzymywała kontakt z Moskwą i walczyła w szeregach przeważnie komunistycznego Oporu [francuskiego - autor], był bardzo enigmatyczny. Jeszcze później oni podziwiali rycerską lojalność metropolity wobec naszej rodziny królewskiej. Tymczasem kiedy on przyjechał do nas po raz pierwszy, niektórzy nawet sądzili, że kto wie, czy nie jest ten młody rosyjski ksiądz bez wykształcenia teologicznego, posiadający wojskową sylwetkę oraz zmęczone bezsennością i ascezą brązowe oczy, po prostu rosyjskim szpiegiem?"’30

Właśnie w taki sposób opisuje rodowita Brytyjka początkowy odbiór hieromnicha Antoniego, którego osoba wywoływała sporo zamieszania nie tylko wśród Anglików, ale też w rosyjskim środowisku emigracyjnym w Londynie. Dochodziło do tego, że po nabożeństwie w świątyni, którą wspólnota Patriarchatu Moskiewskiego dzieliła z Kościołem zagranicznym, ci ostatni ponownie wyświęcali prezbiterium! ${ }^{31}$ Po kilku latach, kiedy ojciec Antoni opanował angielski w wystarczającym stopniu, stosunek do jego osoby uległ zmianie, mimo to środowisko duchowieństwa i parafian Kościoła zagranicznego przez bardzo długi czas utrzymywało negatywną percepcję hierarchy, można sądzić, do czasu zjednoczenia obydwu jurysdykcji.

Choć na początku pobyt w Anglii dla nowego misjonarza nie był łatwy, z czasem na polu społecznym i religijnym biskup Antoni zyskiwał coraz większą popularność,

${ }^{29}$ Антоний Митрополит Сурожский, Труды. Книга вторая, Москва 2007, s. 50.

${ }^{30}$ А. Пайман, Митрополит Антоний Сурожский: иностранеи в Англии, [w:] Человек в богословии митрополита Антония Сурожского. Доклады Второй международной конференции 11-13 сентября 2009 г., Москва 2013, ss. 77-78.

${ }^{31}$ Ibidem. 
przejawem czego miały być częste zaproszenia na wykłady uniwersyteckie i audycje radiowe. Stał się częstym gościem w rozgłośni BBC, która zlecała mu wystapienia radiowe, dzięki którym jego przekaz religijny docierał do większej liczby osób nie tylko w Wielkiej Brytanii, ale i w Związku Radzieckim. Nieważne, czy mówił w radio, przemawiając do publiczności czy prowadząc nabożeństwa w cerkwi, całą jego pracę można było określić ogólnie jako ewangelizacja. Przodował w tym. Jego kazania były zwykle krótkie: mawiał, że kazanie nie powinno trwać dłużej niż dziesięć minut. Były celne, trafiające $\mathrm{w}$ istotę rzeczy danego fragmentu.

Warto w tym momencie wspomnieć o znaczącym fakcie z życia Antoniego Blooma, potwierdzającego jego wyjątkową osobowość i zdolności ewangelizacyjne. Dzięki głoszeniu przez metropolitę Dobrej Nowiny wśród brytyjskich hippisów, część z nich ostatecznie znalazła Boga w Kościele prawosławnym. Jednakże efekty pracy duszpasterskiej hierarchy przejawiły się przede wszystkim w powstawaniu diecezji Surożskiej, ze stale wzrastającą liczbą parafii oraz tak zwanych wspólnot eucharystycznych, czyli miejsc, gdzie mimo braku wyodrębnionej parafii, z błogosławieństwa jego ekscelencji, regularnie odbywały się nabożeństwa liturgiczne. Ostatecznie strategia ta doprowadziła do rozwoju całej diecezji, która u schyłku życia metropolity w 2003 roku osiagnnęła liczbę 53 parafii i wspólnot.

Choć apogeum wydawnicze dorobku homiletycznego metropolity nastąpiło po jego śmierci, warto podkreślić, że do tego czasu opublikowano ponad trzysta różnych pozycji wydawniczych, począwszy od artykułów, a kończąc na kilkusetstronicowych dziełach. Pierwszym z nich była książka Living Prayer. Jedna z pełniejszych bibliografii hierarchy z 2007 roku liczyła ponad 430 pozycji w językach angielskim, greckim, niemieckim, francuskim i rzecz jasna - rosyjskim. W tym roku z błogosławieństwa nowego hierarchy diecezji łódzko-poznańskiej, biskupa Atanazego, zostało opublikowane pierwsze dzieło metropolity Antoniego w języku polskim - Obraz Boży w czlowiek $u^{32}$.

Metropolita Antoni Bloom zmarł 4 sierpnia 2003 roku na raka. O chorobie dowiedział się w lutym tegoż roku, walczył z nią sześć miesięcy. Osobliwym aspektem śmierci hierarchy było objawienie mu jej dokładnej daty, które nastapiło kilka miesięcy wcześniej. Ksiądz John Lee, opiekujący się hierarchą w ostatnim okresie jego życia, jako jedyny miał dowiedzieć się o tym fakcie. Opisał to w sposób następujący:

„Kiedy metropolita Antoni zachorował, byłem tą osobą, która woziła go na wszystkie konsultacje i zabiegi. Kiedy po raz pierwszy przyjechaliśmy na konsultację do specjalisty, wszedłem z nim do gabinetu, ponieważ we wszystkich dokumentach w Anglii zapisywał mnie jako najbliższą rodzinę. Pierwotna opinia specjalisty była bardzo pozy-

${ }^{32}$ A. Bloom, Obraz Boży w człowieku, red. i wprowadz. A. Kucy, thum. A. Kucy i inni, Łódź, Aleksy Kucy, 2018. 
tywna, jak mówią lekarze 'optymistyczna'. Wracając do auta powiedziałem mu: 'No to można być spokojnym, prognozy są zadawalające'. Ekscelencja odpowiedział: 'Nie, lekarz nie ma racji'. Wtedy dodałem: 'Od czasu, kiedy ekscelencja był lekarzem, minęło dużo czasu. Dlaczego ekscelencja jest taki pewny?' Odpowiedział: 'Wczoraj miałem sen: przyszła do mnie moja babcia, trzymając w ręku kalendarz. Nic mi nie mówiła, po prostu trzymała kalendarz przede mną. Dni lutego, marca, kwietnia, maja, czerwca przemijały bardzo szybko. Kiedy doszła kolej lipca dni spowolniły się, a w sierpniu prawie się zatrzymały i zakończyły się na 4 sierpnia. Wtedy sen się zakończył"'”33.

Prześledziwszy drogę życiową hierarchy od urodzenia do jego błogosławionej śmierci, można go uznać za wzór prawdziwie chrześcijańskiej osobowości, która w sposób absolutny poświęciła siebie niosąc posługę ludziom i Kościołowi. W tym znaczeniu można istotnie nazwać go człowiekiem Kościoła. Metropolita Antoni Bloom nie wyobrażał sobie życia bez liturgii, funkcjonowania w jakimś nieokreślonym bycie poza Kościołem. Gdy mówił o modlitwie, to tak jak o powietrzu, którym bez przerwy oddychał i bez którego natychmiast by umarł. Nie jest to patetyczne stwierdzenie. Wielu ludzi traktuje modlitwę jako swego rodzaju formalność, która im szybciej się wypełni, tym lepiej. Ekscelencja był przeciwieństwem tej postawy, ponieważ potrafił w całości oddać się modlitwie kontemplacyjnej, zaś objawienia intelektualne, które temu towarzyszyły, uznane zostały przez jego adeptów jako namacalny dowód wybraństwa. Centrum jego życia sakralnego niewątpliwie był Chrystus, stanowiący Uniwersum jego myśli.

Biorąc pod uwagę osobowość metropolity Antoniego, jego drogę życiową, efekty pracy duszpasterskiej i całokształt działalności misyjnej, z pewnością należy stwierdzić, że był to unikalny i wyjątkowy przedstawiciel rosyjskiej emigracji XX wieku. Mamy podstawy przypuszczać, że w odpowiednim czasie zostanie ogłoszony świętym Kościoła prawosławnego.

\section{Literatura}

Bloom A., Obraz Boży w człowieku, red. i wprowadz. A. Kucy, tłum. A. Kucy i inni, Łódź, Aleksy Kucy, 2018, 349 ss.

Crow G., This Holy Man: Impressions of Metropolitan Anthony, New York 2006.

${ }^{33} \mathrm{~W}$ nieco innej wersji tego samego dialogu metropolita wprost powiedział na koniec rozmowy: „Umrę 4 sierpnia”. Zob. Ли И. (протоиерей), Добрый плод, [w:] О Митрополите Сурожском Антонии. Сборник материалов к 10-летию со дня преставления, Лондон 2013, s. 17. 
Антоний Митрополит Сурожский, Труды. Книга вторая, Москва 2007.

Антоний Митрополит Сурожский, Человек перед Богом, Москва 2000.

Гончаренко О., Миссия русской эмиграции в ХX веке, [w:] http://mir-politika. ru/3521-missiya-russkoy-emigracii-v-hh-veke.html [dostęp: 20.06.2018].

Грезин И., Николай Скрябин: первый российский консул в Лозанне, „Наша Газета", [w:] http://www.nashagazeta.ch/news/12530 [dostęp: 21.06.2018].

Духовное наследие митрополита Антония Сурожского. Материаль Первой международной конференции 28-30 сентября 2007 г. Москва, red. Е. Майданович, Е. Садовникова, М. Уманцева, Москва 2008.

Зернов Н., Русское религиозное возрождение ХХ века, Paris 1991.

Ильин И., Кризис Безбожия, Москва 2005.

Митрополит Антоний Сурожский, Быть Русской Церковью богослужебно, богословски, эмочионально, „Церковный вестник” 2002, nr 23 (292), [w:] http:// www.taday.ru/text/551475.html [dostęp: 27.06.2018].

Назаров М., Миссия русской эмигращии, Москва 1994.

Нивьер А., Православные священнослужители, богословы и иерковные деятели русской эмиграции в Западной и Центральной Европе 1920-1995. Биографический справочник, Москва 2007.

О Митрополите Сурожском Антонии. Сборник материалов к 10-летию со дня преставления, Лондон 2013.

Петр (Мерещинов) игумен, Жизнь православного христианина в современном мире (на примере митрополита Антония), [w:] Духовное наследие митрополита Антония Сурожского. Материалы Первой международной конференциии 28-30 сентября 2007 г. Москва, red. Е. Майданович, Е.Садовникова, М.Уманцева, Москва 2008.

Прот. А. Шмеман, Собрание статей 1947-1983, Москва 2009.

Протоиерей Александ Мень, Библиологический Словарь, Москва 2002.

Струве Н., Православие и Культура, Москва 2000.

Человек в богословии митрополита Антония Сурожского. Доклады Второй международной конференции 11-13 сентября 2009 г., Москва 2013.

\section{Filmografia}

Апостол любви: выбор пути, reż. В. Матвеева, Санкт-Петербург 2005. Апостол любви: Сеятель, reż. В. Матвеева, Санкт-Петербург 2008. Апостол любви: встречи в России, reż. В. Матвеева, Санкт-Петербург 2007. Митрополит Сурожский Антони. Беседьл. Октябрь 1993. Почемуя принадлежу $\kappa$ РПЦ, reż. В. Матвеева, Санкт-Петербург 2006. 


\section{References}

Antonij Mitropolit Surozhskij, Trudy. Kniga vtoraya [Works. Second book], Moskva 2007.

Antonij Mitropolit Surozhskij, Chelovek pered Bogom [God and Man], Moskva 2000.

Bloom A., Obraz Boży w człowieku [The Divine Image in the Man], A. Kucy (Ed.), trans. A. Kucy et al., Łódź, Aleksy Kucy, 2018, 349 pp.

Chelovek v bogoslovii mitropolita Antoniya Surozhskogo. Doklady Vtoroj mezhdunarodnoj konferencii 11-13 sentyabrya $2009 \mathrm{~g}$. [The person in divinity of the metropolitan Anthony Surozhsky. Reports of the Second international conference on September 11-13, 2009], Moskva 2013.

Crow G., This Holy Man: Impressions of Metropolitan Anthony, New York 2006.

Duhovnoe nasledie mitropolita Antoniya Surozhskogo. Materialy Pervoj mezhdunarodnoj konferencii 28-30 sentyabrya $2007 \mathrm{~g}$. Moskva [Spiritual heritage of the metropolitan Anthony Surozhsky. Materials of the First international conference on September 28-30, 2007 Moscow], E. Majdanovich, E. Sadovnikova, M. Umanceva (Eds.), Moskva 2008.

Goncharenko O., Missiya russkoj emigracii XX veke [Mission of the Russian emigration in the XX century], [w:] http://mir-politika.ru/3521-missiya-russkoyemigracii-v-hh-veke.html [accessed: 20.06.2018].

Grezin I., Nikolaj Skryabin: pervyj rossijskij konsul v Lozanne [Nikolay Scriabin: the first Russian consul in Lausanne], "Nasha Gazeta" [Our Newspaper], Available at: http://www.nashagazeta.ch/news/12530 [accessed: 21.06.2018].

Il'in I., Krizis Bezbozhiya [Godlessness crisis], Moskva 2005.

Mitropolit Antonij Surozhskij, Byt'Russkoj Cerkov'yu bogosluzhebno, bogoslovski, emocional'no [To be the Russian Church a ceremonical, theological, emotionally], "Cerkovnyj vestnik" [The Church Bulletin] 2002, nr 23 (292), Available at: http://www.taday.ru/text/551475.html [accessed: 27.06.2018].

Nazarov M., Missiya russkoj emigracii [Mission of the Russian emigration], Moskva 1994.

Niv'er A., Pravoslavnye svyashchennosluzhiteli, bogoslovy i cerkovnye deyateli russkoj emigracii v Zapadnoj i Central'noj Evrope 1920-1995. Biograficheskij spravochnik [Orthodox priests, theologians and church figures of the Russian emigration in Western and Central Europe of 1920-1995. Biographic reference book], Moskva 2007.

O Mitropolite Surozhskom Antonii. Sbornik materialov k 10-letiyu so dnya prestavleniya [About the Metropolitan of Sourozh Anthony. The collection of materials for the 10 anniversary from the date of a prestavleniye], London 2013. 
Petr (Mereshchinov) igumen, Zhizn 'pravoslavnogo hristianina v sovremennom mire (na primere mitropolita Antoniya) [Life of the orthodox Christian in the modern world (on the example of the metropolitan Anthony)], [w:] Duhovnoe nasledie mitropolita Antoniya Surozhskogo. Materialy Pervoj mezhdunarodnoj konferencii 28-30 sentyabrya $2007 \mathrm{~g}$. Moskva [Spiritual heritage of the metropolitan Anthony Surozhsky. Materials of the First international conference on September 28-30, 2007 Moscow], E. Majdanovich, E. Sadovnikova, M. Umanceva (Eds.), Moskva 2008.

Prot. A. Shmeman, Sobranie statej 1947-1983 [Collection of articles 1947-1983], Moskva 2009.

Protoierej Aleksand Men', Bibliologicheskij Slovar'[Bibliological Dictionary], Moskva 2002.

Struve N., Pravoslavie i Kul'tura [Orthodoxy and Culture], Moskva 2000.

Zernov N., Russkoe religioznoe vozrozhdenie XX veka [Russian religious revival of the 20th century], Paris 1991.

\section{Films}

Apostol lyubvi: vybor puti [Apostle of love: choice of a way], prod. V. Matveeva, Sankt-Peterburg 2005.

Apostol lyubvi: Seyatel' [Apostle of love: Sower], prod. V. Matveeva, Sankt-Peterburg 2008.

Apostol lyubvi: vstrechiv Rossii [Apostle of love: meetings in Russia], prod. V. Matveeva, Sankt-Peterburg 2007.

Mitropolit Surozhskij Antoni. Besedy. Oktyabr' 1993. Pochemu ya prinadlezhu k RPC [Metropolitan of Sourozh Antoni. Conversations. October, 1993. Why I belong to ROCh], prod. V. Matveeva, Sankt-Peterburg 2006. 